\title{
Relationship between Entrepreneurial Characteristics from Islamic Perspective and the Performance of Small and Medium-Sized Businesses (A Study of SMEs in Indonesia)
}

\section{Dini Lisnawati and H. Eeng Ahman}

Doctoral program student of Management, Universitas Pendidikan Indonesia, 2, Lecturer of Universitas Pendidikan Indonesia, Jl. Setia Budi 229, Bandung, Indonesia

\section{Abstract}

This study aims to analyze the relationship between entrepreneurial characteristics from Islamic perspective and the performance of SMEs of Muslim entrepreneurs in Indonesia. Factors suspected of affecting entrepreneurial characteristics from Islamic perspective are fathanah (wisdom), amanah (trustworthy), siddiq (truthfulness) and tabligh (advocacy). The study method used an explanatory survey with data

Corresponding Author:

Dini Lisnawati

dinilisnawati@student.upi.edu

Received: 10 February 2019

Accepted: 14 March 2019

Published: 28 March 2019

Publishing services provided by Knowledge E

(c) Dini Lisnawati and $\mathrm{H}$. Eeng Ahman. This article is distributed under the terms of the

Commons Attribution License, which permits unrestricted use and redistribution provided that the original author and source are credited.

Selection and Peer-review under the responsibility of the ICIEBP Conference Committee.

\section{G OPEN ACCESS} collection techniques with technical questionnaires and interviews to 50 fashion muslim entrepreneurs in Bandung-West Java. The collected data is analyzed by using SPSS. The result from the study shows that Entrepreneurial characteristic from Islamic perspective has relationship with the performance of SMEs. This finding implies that in order to improve the performance of SMEs especally for Muslim entrepreneurs must be empowered their self to have the strong motivation to excel their potentials sources based on the Islamic teaching in Quran and Sunnah.

Keywords: Entrepreneurial characteristic; Islamic entrepreneurship, Performance of SMEs; Fashion.

\section{Introduction}

Muslim population in Indonesia is about $87.18 \%$ (BPS: 2017). The Muslim population are expected to support the economic growth in Indonesia. Meanwhile, by the increasing of the number Muslim population in Indonesia has also increased the demand of the Islamic clothing, especially the hijab or Muslim fashion.Thus, the popularity of the hijab and Muslim fashion in Indonesia has been on the rise. A growing number of Indonesian women are wearing veil or headscarf in the world's most populous Muslim majority market. Muslimwear has evolved from a religious and cultural movement to a fashionsavvy trend and booming industry. According to data from BPS (2013), the number of 
companies engaged in the fashion sector reached 1,107,955 units. Around $10 \%$ of them are large companies, 20\% are medium enterprises and 70\% are small enterprises . Of the 750,000 SMEs engaged in the clothing sector in Indonesia, around 30\% of them are muslimwear producers, with large companies occupying $40 \%$, while small and medium enterprises each occupy 30\% respectively of the market (Global Business Guide Indonesia - 2016).

Entrepreneurs who have a firm commitment of holding shari'ah rules in entrepreneurship, is expected to be a driver of economic growth. Hence, the entrepreneurs are expected to encourage a business growth climate with creativity and innovation. Entrepreneurship as a business management topic area is important to contemporary and traditional Islamic principles. Islam can be considered an entrepreneurial religion due to its historical development, which originates from merchants and traders. Islamic entrepreneurship combines the religious beliefs of Islam with the business notion of what it means to be an entrepreneur. The combination of traditional entrepreneurship studies focusing on innovation, risk taking and forward thinking need to be integrated into religious beliefs in order to understand the role of Islamic entrepreneurship in society (Ratten, 2015). The main problems of the majority Islamic countries such as Indonesia are lack of investment in people, steady decline in productivity, shortage in employment opportunities, lower of education and depletion of non-renewable natural resources. Moreover, The market of Muslim customers is rising and entrepreneurs are developing (new) products to respond to demand. Given these trends, a reflection on the inter actionbetween Islam and entrepreneurship becomes particularly pertinent (Gümüsay,2015).

\section{Literatur Review}

\subsection{Entrepreneurship and religion}

The intersection of entrepreneurship and religion constructs provides an understanding of how an entrepreneur's heightened consciousness in terms of his/her personal values and beliefs can impact his or her business activities and crucial characteristics of the entrepreneurial process, such as the recognition of opportunities, the creation of new ventures, as well as the operation and growth ofthese firms (Balog et.al,2014).Religious beliefs are intertwined with cultural values and together influence the social desirability of entrepreneurship and the nature of entrepreneurial activity (Dana,2010). Islamic religiosity has the potential benefit of fostering entrepreneurial motivation, enhancing 
performance and commitment to social responsibility (Adamu et al.,2013). Based on the result of the research about entrepreneurship and religion discovered patterns that reflect beliefs and values affecting entrepreneurship (Dana, 2010). The perceptions of the Islamic religion and its impact on entrepreneurial behaviours, from the perspective of those directly involved with the respective religious belief and entrepreneurial behaviour (Davis,2013).

\subsubsection{History of entrepreneurship Islamic perspective}

Although religion has been largely eglected in organisations and management studies, there are still some initial efforts trying oriented to match the adequate relevance of religion in these studies since religion plays a central role in many societies (Tracey et al., 2014). For example, entrepreneurs' religion influence has been considered a variable to entrepreneurship researches from various thematic areas such as business management, psychology, sociology and economy (Carneiro-daCunha,et.al,2015). Entrepreneur and entrepreneurship have a special place in Islam. An Islamic entrepreneurship model is sourced from the al-Quran and al-Hadith. Islam sees everything as a comprehensive element in life, including entrepreneurship. Therefore, in Islam, entrepreneurship includes all aspects of life, whether it is for the world or the hereafter (Salwa et.al,2013).

\subsubsection{Entrepreneurship from Islamic perspective}

An entrepreneur can be difined as one who creates a new business in the face of risk and uncertainty for the purpose of achieving profit and growth by identifying opportunities and assembling the necessary resources to capitalize on them(Zimmerer, Scarborough $\&$ Wilson, 1996). An entrepreneur, in the face of risk and uncertainty, combines resources in new and different ways to create value, often accomplished via the formation and development of a new business venture. Entrepreneurship is also very much alive in existing companies. It can be found in all sectors of society, not just in business (Zimmerer, Scarborough \& Wilson, 1996). Since Islamic religion, which mentions to all hidden and obvious angles of human life, is complete religion, it is possible to obtain all material surviving guidance of course tothe extent of our understanding by investigating it. Maybe, there is beautiful definition about entrepreneurship by prophet. In Islamic culture, human is creature who enters to world after the world creation steps as though 
world is incomplete without it, so God gave the status of Khalifa of God and assigned attempt as human growth and felicity. (Talatapeh et.al, 2016).

In Islamic culture, human is creature who enters to world after the world creation steps as though world is incomplete without it, so God gave the status of Khalifa of God and assigned attempt as human growth and felicity. (Babaei Talatapeh, 2015). Entrepreneurship from Islamic Perspective (EIP) is more than a simple summation of Islam andentrepreneurship. It is based on three interwoven pillars.The first pillar, based on the definition of entrepreneurship,is the pursuit of opportunities. The second pillar is socioeconomic or ethical. Effectively, EIP is guided by a set of norms, values and recommendations. The third pillar is religio-spiritual and links people to God with the ultimate objective of pleasing Allah. These pillars are interlinked.Pillars two and three are not simply added. All three pillars shape each other. Furthermore, these pillars have specific scriptural sources as well as institutions and processes of interpretation.

EIP thus contains its own methodology of approaching its understanding. It needs to be comprehended and analyzed holistically containing entrepreneurial pursuit, religiously-shaped values, concrete Islamic obligations, community-influence, scriptural sources and an ecosystem of actors, and institutions which provide an interpretation for this religio-spiritual lens (Gümüsay,2014). there is scholarly tradition from which one can explore Islamic economic theory in general,and entrepreneurship specifically, from an Islamic perspective. Throughout Islamic history Muslim scholars have written on the economic teachings of Islam and its application to what we have come to call entrepreneurial activity (Siddiqi, 1972; Khan, 1994, Davis:2013).

The Qur'an(believed to be the revealed word of God by Muslims), Sunnah (the practices of the Prophet Muhammad), Fiqh(Islamic jurisprudence), social thought and historical experience have served as the Islamic basis for the confabulation of Islamic economic activity (Davis,2013).

\subsubsection{The context of an Islamic entrepreneurship}

Entrepreneurship and business in Islamic perception have a special place. Islam encourage people to become entrepeneurs base on The Holy Qur'an and the Hadith of The Prophet Muhammad S.A.W as the basic principles, rules and ways for doing the business. 


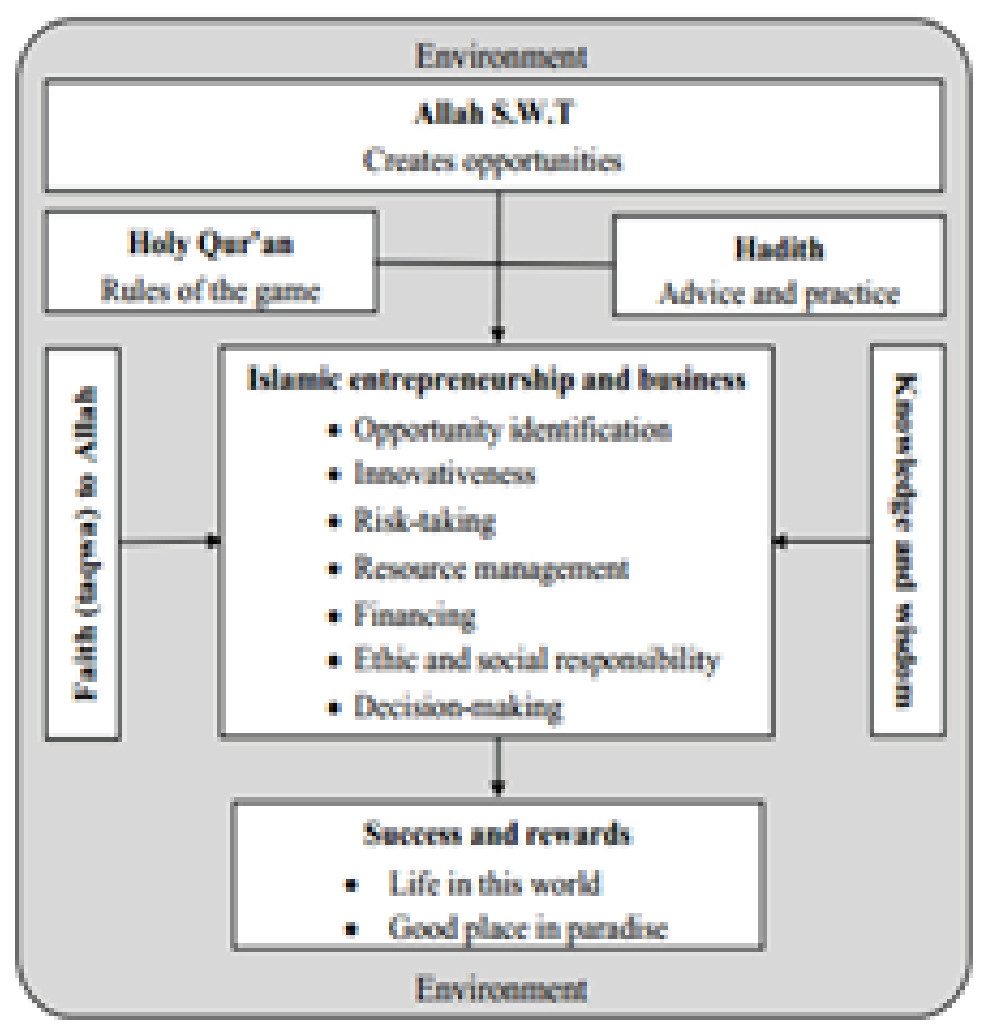

Figure 1: Model of Islamic entrepreneurship and business (Source: (Ramadani et al,2015)).

\subsubsection{Islamic entrepreneurial characteristics}

The role of Islamic ethics in business helps motivate entrepreneurs to contribute to society. It is important to facilitate Islamic entrepreneurship and management in order to create a positive attitude towards economic development. There is optimism about the adoption of entrepreneurial management practices in Islamic countries around the world. The intersections of Islam, entrepreneurship and management are interesting due to the increasing interest in religious forms of business (Ramadani et.al,2016).

Some of characteristics have been identified to be necessary for entrepreneurs to perform better in their businesses. Such characteristics include commitment and determination, desire for responsibility, opportunity obsession, tolerance for risk;ambiguity; uncertatinty, self confindence, creativity and flexibility, desire for immediate feedback, high level of energy, motivation to excel, orientation to the future, willingness to learn from failure, leadership ability (Timmons,1990). Some characteristics have been identified to be necessary for entrepreneurs to perform better in their businesses. Such characteristics include personality, innovation, risk taking, self-actualisation, innovation and demographic variables (Akeem \& Adekanmbi,2016). 
According to the hadith presented, it is clear that the Prophet gave instructions to his followers, especially the entrepreneurs or traders to link businesses with the demands of religion. Therefore, it is clear that Islam calls for his followers engaged in the entrepreneurial world to practice the values in all transactions carried out and denounced against those who act outside the requirements of the religion. Since entrepreneurial practices is part of understanding of religion, certainly increasing of the performance activities undertaken should be synergized to increase the values that need to be understood and practiced by the Muslim entrepreneur (Abdullah, .2013).

Successful entrepreneurs from of Islamic perspective are entrepreneurs who have high commitment and appreciation to the Islamic way of life is perfect in every aspect of life. Strong faith in religion is the concrete basis to individual entrepreneurs and subjugates Muslims to put ourselves in a true to the God Almighty. These trust and confidence demanded the entrepreneurs to get to know the fact of her as a slave and a trustee is responsible for implementing the decree of Allah SWT. Impact, it will produce the characteristics of individual taqwa, which tends to the ways of charity to gain the success (Abdullah, .2013).

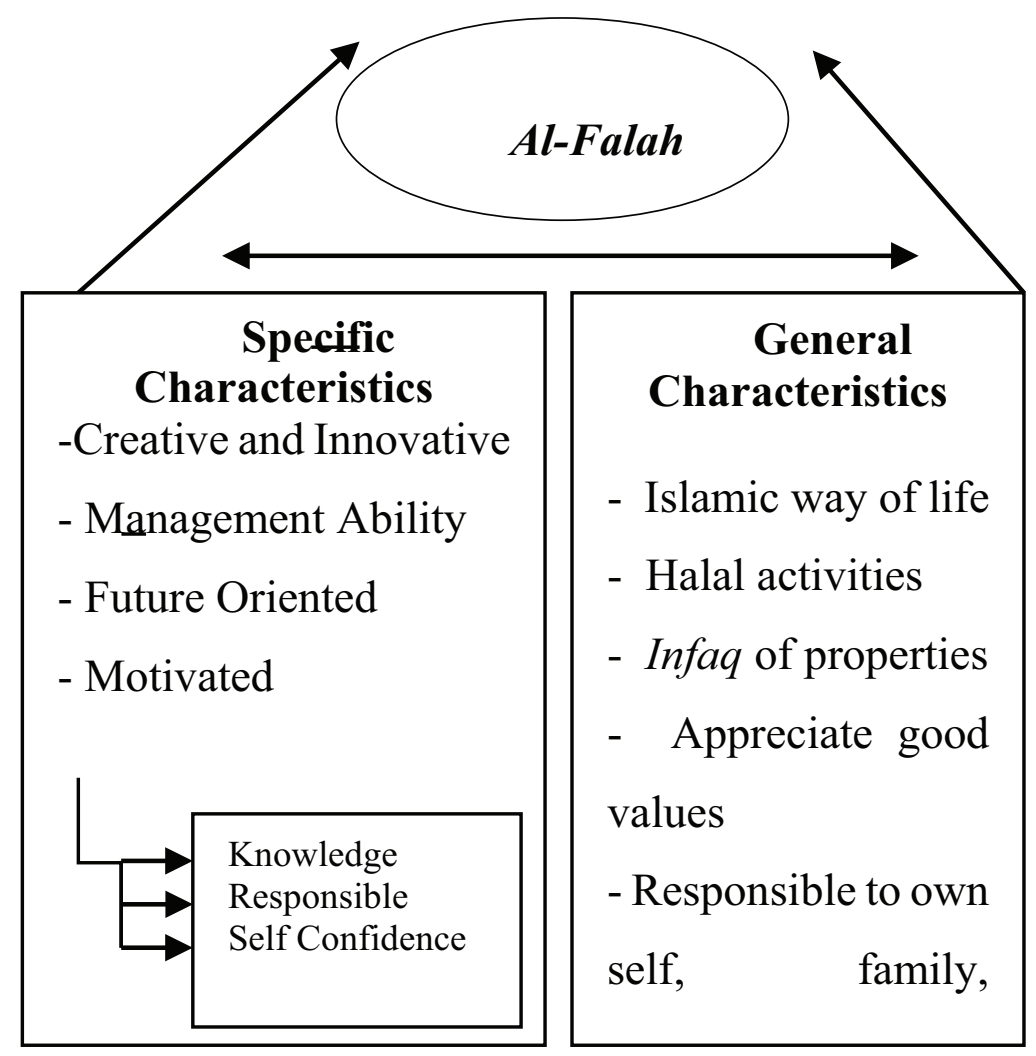

Figure 2: Successful Entrepreneur (Sources: Successful Entrepreneur (Abdullah, 2013)).

Entrepreneurship in Islamic perspective provides rules and ways to entrepreneurs relating the characteristics to be the successful entrepreneurs which can be a model 
of entrepreneurial activities. The values embedded in those features which include general and specific values as the essential elements which must be nurtured in the lives of entrepreneurs. Utility values derived from these values will produce dynamic and proactive entrepreneurial individuals. In general, the characteristics of successful entrepreneurs are individuals which have the ability to incorporate general and specific values in all activities related (Abdullah, 2013).

The credibility and capability of the Prophet Muhammad PBUH was in his four superior characters, namely FAST (Fathonah, Amanah, Shiddiq and Tabligh)(Antonio, 2010).

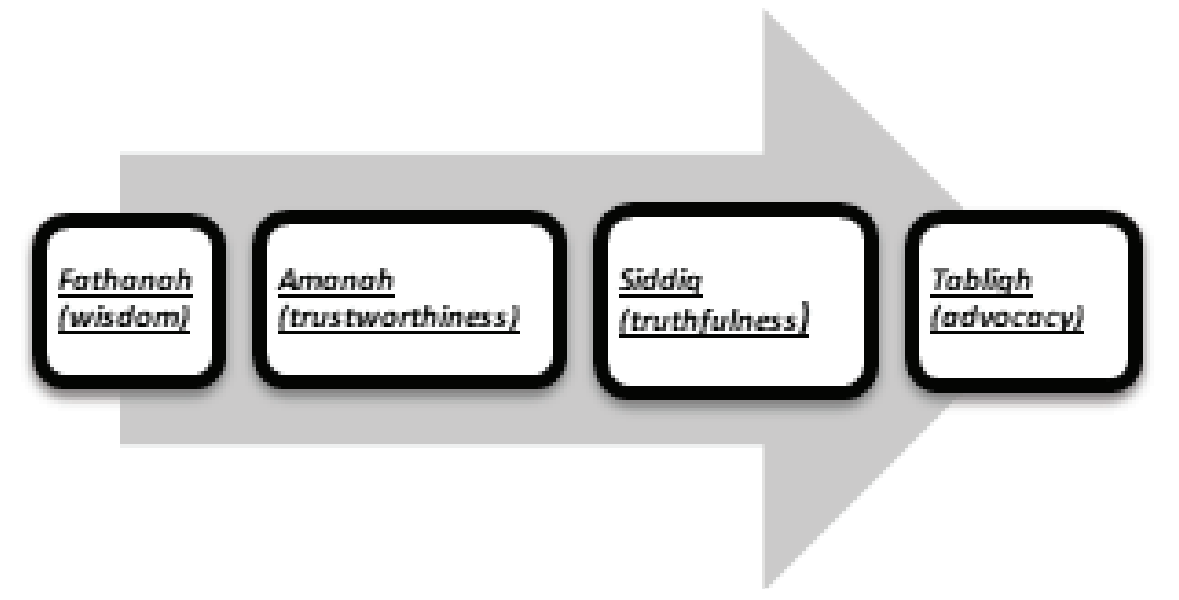

Figure 3: Four superior characters of the Prophet Muhammad PBUH (Sources: Adapted from various sources).

\section{Fathanah (wisdom)}

Wisdom from islamic context means as intelligence and scientific capacity. Wisdom means professionalism. It has the capacity to do something in accordance with well-being. This intelligent meaning leads to the ability to use the mind in various ways (Siswanto, 2016).The expected character of the intelligent nature of the Prophet Muhammad PBUH in the entrepreneurial context is as follows:

(a) Innovative and creative

Creativity and innovative are the skills needed in successful entrepreneurs themselves. Creative skills at the entrepreneurs are the key factor that distinguishes them with other individuals. In other words, creative entrepreneurs can be understood as an individual who has the creativity new ways of looking at issues and opportunities (Abdullah et.al,2013). One hallmark of true entrepreneurs is their ability to adapt to the changing demands of their customers and their business. In this rapidly changing world economy, rigidity often leads the failure. The ability to respond in a flexible manner to constant change requires a high degree of creativity (Zimmerer and Scarborough,1996). 
(b) Orientation to the future

Research has indicated that entrepreneurs who created high growth ventures exhibited a far greater concern for the future than did those entrepreneurs who headed low- and medium-growth ventures (Ginn \& Sexton, 1989). Islam provides opportunity to the entrepreneurs to respond positively in order to stimulate performance of activities. In fact, Islam encourages entrepreneurs to be far-sighted to create and take advantage of this nature to compliance others. They were given freedom by shari'ah' to prosper all the blessings of Allah SWT and treated in the manner permitted by syara' for the benefit of all beings (Abdullah et.al,2013)..

(c) Managerial skills

In Islamic view, successful entrepreneurs need to be equipped with special characteristics which include the values with charisma of a good manager. The characteristics which stated were important because the individuals are constantly focused on the activities planned and give priority to the strategic management priorities (Abdullah et.al,2013).

(d) Motivation to excel

Successful entrepreneurs have the characteristics of individual's passion and desire to excel and meet the high goals that have been planned. To meet these goals, the element of motivation is internal value used to increase the performance of entrepreneurs to strive consistently and willing to accommodate the shortcomings and the challenges faced (Abdullah et.al,2013). Successful entrepreneurs are highly motivated to excel in what they do. They typically are self-starters and appear driven internally to compete against their own self-imposed standards. This need to achieve is bet documented by McClelland (McClelland,1967).

\section{Amanah (trustworthiness)}

Amanah is trustworthy as a reference for the implementation of a sense of responsibility, trust, and honor. In the command contained values that must be cultivated such as honesty, responsibility, commitment, dependability, respect and credibility (Siswanto, 2016). Furthermore, the Prophet Muhammad PBUH and many of his close companions were trustworthy and successful entrepreneurs. He explicitly emphasized the importance of entrepreneurship and encouraged Muslims to actively participate in business and entrepreneurial activity (Faisal et. Al,2013). 
Implementation of the command according to Siswanto (2016) in the context of business is when a Muslim has the following characteristics:

(a) Reliable and responsible

The nature of trust is responsibility. Trustworthy can be a test of faith for a Muslim entrepreneurs and a way to achieve glory. Entrepreneurs feel a personal responsibility for the outcome of ventures in which they are associated. They prefer to be in control of their resources to achieve self-determined goals. This willingness to accept the responsibility for the outcome of the entrepreneurial venture is closely related to the deep desire of entrepreneurs to mantain an internal locus of control (Zimmerer and Scarborough,1996).

(b) Responsive

Responsive means when solving problems quickly and never avoiding any problems.

(c) Objective

Muslim entrepreneurs will always act objectively by analyzing correctly and honestly for the common good.

(d) Accurate

Muslim entrepreneurs will provide solutions according to needs.

(e) Discipline

Muslim entrepreneurs who are disciplined is able to adjust the desire with the rules that apply and always obey the principles so that it can form a culture that is good for himself and the people around him.

Characteristic qualities of the Prophet Muhammad's mandate because he has a quality of self that has qualifications that are worthy of trust. The quality consists of quality of character or morals and expertise.

\section{Siddiq (truthfulness)}

Truthfulness for Muslim entrepreneur is a behavioral asset to build the character in entrepreneurship. In managing their entrepreneurship, Truthfulness is the embodiment of the essence of the value of the nature of the truthfulness. Muslim entrepreneurs who have a spirit of always thinking positively and full of optimism and have far-reaching insight horizons can produce creative and innovative ideas that have an impact on the sustainability of an entrepreneur.

\section{Tabligh (advocacy)}


Advocacy means delivering messages or news (Siswanto, 2016). Advocacy means providing a message and benefits based on the principle of glory that puts the essence of the message of goodness based on Qur'an and Hadith.

The main character that must be possessed by an entrepreneur apart from being creative, innovative, having the courage to face risks, being able to withstand various challenges and being able to seize opportunities and be competitive, there is a main character that is the identity of a Muslim entrepreneur, namely noble character as Muhammad example. Every entrepreneur should make all the moral and behaviors of Muhammad PBUH as an example that is the guide in entrepreneurship.

\subsection{Entrepreneurial characteristis from Islamic perspective and performance of small and medium-sized businesses}

A number of research studies from the last few years about entrepreneurial characteristics and business performance are introduced Empirical evidence supports that an entrepreneur's personal characteristics have a direct effect on the business' performance. (Zhang and Bruning 2011) Entrepreneurial characteristics has become an important aspect in context with business performance and a growing number of studies have been dedicated to entrepreneurship in the last years.(Halim et al. 2011) In a research study by Gupta and Muita (2013). the relationship between entrepreneurial characteristics and the impact they have on the growth of a business venture. The typical characteristics of a successful entrepreneur are innovativeness, the ability to take risks and to co-operate, market and manufacturing knowledge, as well as, business management and marketing skills. Also, the ability to identify and grasp profitable business opportunities, to be able to correct errors effectively, the desire to take risks and a good nose for business are all characteristics of a successful entrepreneur. (Littunen 2000).

The entrepreneurial characteristis are the ability to learn from failure, integrity and reliability, low need for status and power, calculated risk taking, tolerance for ambiguity, stress and uncertainty, persistence, orientation to opportunities and goals, drive to achieve and grow and complete commitment, determination and perseverance (McNeil, et al. 1991). Likewise, entrepreneurial characteristics from Islamic perspective has many characters that similar with entrepreneurial characteristics in general. The Islamic entrepreneurship principles to create wealth. The quest for wealth must joined by proposition, means, administration and utilisation as stipulated by Islam (Abdullah et. 
Al, 2015).Innovation is a major factor of economic growth and performance in the globalised economy (Ramadani et al.,2013). Innovation can be defined as an ability to perform creative solutions in order to enhance people's life and that organisation that do not innovate effectively may be destroyed by those that do (Gerguri et al.,2013).

The holistic characteristics of entrepreneurs from Islamic perspective has inculcated rule of metaphysics which are abstract like sin, merit, hell and heaven that becomes the trigger to human"s behaviour in structuring entrepreneurial development. The implication from the concept of property as trust, test, instrument and its inabsolute ownership will make Muslimpreneurs more careful in searching and spending. Thus, characteristics of entrepreneurs from Islamic perspective should differ from other entrepreneurs in their motives and aims. It is hoped that if they are able to manage their business successfully, they should also have good performance in terms of faith and belief towards Allah SWT (Hamid et.al,2011).

\subsection{Small and medium-sized businesses (SMEs)}

The key characteristics of a small firm that has been used extensively by governments and scientists around the world, according to management literature, is the one used by the Bolton Committee in its 1971 Report on Small Firms. The economic definition regarded firms as small if they satisfied the following three criteria (Piperopoulos,2016):

1. They had a relatively small share of their market place.

2. They were managed by owners or part-owners in a personalized way and not through a formalized management structure.

3. They were independent businesses, in a sense of not forming part of a larger enterprise

The definition of SMEs according to the Ministry of Industry, a Small Enterprise is a business establishment with assets (excluding land and building) of less than 200 million rupiah; Medium Enterprises are from 200 million up to 5 billion rupiah; and firms of more than 5 billion rupiah are considered as Les (Large enterprises). A different definition is given by the Central Bureau of Statistics (Biro Pusat Statistik [BPS]), which classifies enterprise systematically according to the number of fulltime employees. From 0 to 4 workers a firm is classified as a Cottage or Household Enterprise (CHE), those with 5 to 19 workers as Small Enterprises (SEs), and those with more than 19 as Medium Large Enterprises (MLEs). Small businesses, the tangible manifestation of 
entrepreneurship, are considered to be in a better position than larger firms to assume a more expedient role in the economic development, especially within the economies of developing countries (Kayed and Hassan,2010).

Based on the above discussion, it is hypothesized that:

Entrepreneurial characteristics from Islamic perspective have the relationship with performance of SMEs.

\subsection{Research \& methodology}

The methodology of this study is the survey design method to obtain data which were processed with SPSS using descriptive statictical tool to answer the research hypotheses.

\subsubsection{Population and sampling}

In order to test the aforementioned hyphothesees, a quantitative study was conducted in Bandung. The population consists 50 Muslim fashion entrepreneurs in Muslim fashion business. A simple random sampling was employed to select the respondent among the study population.

\subsubsection{Measures}

All constructs in this research were measured uing multiple items, five-point Likert scale ranging from strongly disagree to strongly agree. The entrepreneurial characteristics will be evaluated from the four characteristics of Muhammad Prophet is a man who can be a good example for all of the mankind. He got Al-Amin tytle (a believable human). Muhammad Prophet got that tytle because his good characters which is Siddiq (Honest), Amanah (Responsible), Fathanah (Capable/Clever), and Tabligh (Convey) (Hasib et.al, 2017).Finally, the performance of SMEs scale consist of eight items to measure the cumulative of the performance of SMEs. These instruments of the performance are namely improved profitability, improved return on invesment, improved market share, improved customer loyalty. The measurement of this scale consist of five-point Likert type scale ranging from 1 (very unsatisfied) to 5 (very satisfied).

The questionnaire had two sections:

1. Profile of the respondent (age,gender, education background,marital status) and Profile of the respondent's business (annual sales, business experience) 
2. Variables questionnaire (entrepreneurial characteristics from Islamic perspective and performance of SMEs)

TABLE 1: demographic characteristics of the respondents.

\begin{tabular}{|c|c|c|}
\hline Demographic variable & Frequency & Percent \\
\hline \multicolumn{3}{|l|}{ Gender } \\
\hline - Male & 12 & 24 \\
\hline - Female & 38 & 76 \\
\hline \multicolumn{3}{|l|}{ Age group } \\
\hline - Below 30 and 30 years & 36 & 72 \\
\hline - 31-40 years & 9 & 18 \\
\hline - 41-50 years & 3 & 6 \\
\hline - 51 years and above & 2 & 4 \\
\hline \multicolumn{3}{|l|}{ Marital status } \\
\hline - Single & 18 & 28 \\
\hline - Married & 32 & 72 \\
\hline \multicolumn{3}{|l|}{ Highest level of education } \\
\hline - Junior High School & 5 & 10 \\
\hline - Senior High School & 34 & 68 \\
\hline - Diploma & 2 & 4 \\
\hline - Degree & 9 & 18 \\
\hline \multicolumn{3}{|c|}{ Years of business experience } \\
\hline - $1-3$ years & 33 & 66 \\
\hline - 4-5 years & 8 & 16 \\
\hline - 6-10 years & 8 & 16 \\
\hline - More than 10 years & 1 & 2 \\
\hline \multicolumn{3}{|c|}{ Gross Revenue (rupiah) *monthly } \\
\hline - 50-100 million & 46 & 92 \\
\hline • $101-250$ million & 3 & 6 \\
\hline • 251-500 million & 1 & 2 \\
\hline
\end{tabular}

\section{Result and Discussions}

Since the instrument of this study was self-constructed by the researcher, there arises a need to conduct a pilot study to show the reliability of the instrument. The result of the pilot test showed a Cronbach's Alpha value of 0.790 . Hence, the reliability 
level of the instrument is high. The $\mathrm{R}^{2}$ value of that there is significant relationship between entrepreneurial characteristics from Islamic perspective and the performance of SMEs is 0.200 . The result indicates that there is a positive relationship between entrepreneurial characteristics from Islamic perspective an SMEs performance of Muslim fashion entrepreneurs. The study also shows that to be a succesful Muslim entrepreneurs, they must have the Muslim characteristics. Business will bring benefits to the entrepreneurs as long as correctly and properly.. Hence, the four pillars of entrepreneurial characteristics from Islamic perspective create wealth to serve others. It leads the entrepreneurs to gain the successful in the world and hereafter.

Additional study needs to be done that explores the entrepreneurial characteristic from Islamic perspectiveamong Mulims comunities in various fields. On the other hand, this study was also been confirmed that the number of men entrepreneurs are lower than men. It was caused that in Muslim Fashion business, women has focused on the business fashion as their passion. Future research may conduct in different business, context,community or in other nation. The comparative analysis is very important in many different demographic variables. Hence, research or study about Islamic entrepreneurship might be more in the future.Further research can be in other critical areas such as Islamic funding, shari'ah business, corporate social resposibility in Islamic context, business ethics in Islamic perspective for SMEs also need to be more explored.

\section{References}

[1] A. B. Ummi Salwa, A. S. Shahbudin, and K. Jusoff. (2013). "Religion and business values for muslimpreneurs," Middle-East Journal of Scientific Research. Religion and Business Values for Muslimpreneurs. Middle-East Journal of Scientific Research (Research in Contemporary Islamic Finance and Wealth Management), vol. 13, pp. $61-68$.

[2] Abdullah, S. (2013). The characteristics of successful entrepreneurs from islamic perspective. Journal of Islamic and human advanced research, 3(6), 322-345.

[3] Adamu, I. M., Kedah, Z., \& Osman-Gani, A. M. (2013). Entrepreneurial motivation, performance and commitment to social responsibility: toward future research. International Journal of Entrepreneurship and Small Business, 18(2), 194-210.

[4] Ahmad, M., \& Kadir, S. A. (2013). Characteristics of entrepreneurs and the practice of Islamic Values in influencing the success of small medium enterprises in Kelantan and Selangor. Journal of Social and Development Sciences, 4(5), 229. 
[5] Ajani Akeem, O., \& Adekanmbi, O. (2016)Relationship between Entrepreneurial Characteristics and Performance of Small and Medium Scale Enterprise (A Study of SMEs in Yaba LCDA).

[6] Antonio, Muhammad Syafi'i, (2010)Muhammad PBUH: The Super Leader Super Manager.Jakarta: proLM Center dan Tazkia Publishing.

[7] Balog, A. M., Baker, L. T., \& Walker, A. G. (2014). Religiosity and spirituality in entrepreneurship: a review and research agenda. Journal of management, spirituality \& religion, 11(2), 159-186.

[8] Beekun, R. and Badawi, J.A. (1999),Leadership: An Islamic Perspective, Amana Publications,Beltsville, MD.

[9] Beekun, R. and Badawi, J.A. (2005), "Balancing ethical responsibility among multiple organizational stakeholders: the Islamic perspective”,Journal of Business Ethics, Vol. 60 No. 2, pp. 131-45.Business, Vol. 20, No. 1, pp.63-69.

[10] Dana, L.P. (2009) 'Religion as an explanatory variable for entrepreneurship', International Journal

[11] Dana, L.P. (2010) Entrepreneurship and Religion, Edward Elgar, Cheltenham, UK.

[12] Dana, L.P. and Dana, T.E.(2005) 'Expanding the scope of methodologies used in entrepreneurship

[13] Davis, M.K. (2013) ‘Entrepreneurship: an Islamic perspective', Int. J. Entrepreneurship and Small

[14] Faizal, P. R. M., Ridhwan, A. A. M., \& Kalsom, A. W. (2013). The entrepreneurs characteristic from al-Quran and al-Hadis. International Journal of Trade, Economics and Finance, 4(4), 191.

[15] Ginn, C. W., \& Sexton, D. L. (1989). Growth: A vocational choice and psychological preference. Frontiers of Entrepreneurship Research. Wellesley, Massachusetts: Babson College, 1-12.

[16] Gümüsay, A. A. (2015). Entrepreneurship from an Islamic perspective. Journal of Business Ethics, 130(1), 199-208.

[17] Gupta, A. and Muita, S.(2013). Relationship between Entrepreneurial Personality, Performance, Job Satisfaction and Operations Strategy: An Empirical Examination. International Journal of Business and Management, Volume 8, Number 2, p. 86-95.

[18] Halim, M., et al.(2011).The Measurement of Entrepreneurial Personality and Business Performance in Terengganu Creative Industry. International Journal of Business and Management, Volume 6, Number 6, p. 183-192.

[19] Kayed, R. N., \& Hassan, M. K. (2010). Islamic entrepreneurship: A case study of Saudi Arabia. Journal of developmental entrepreneurship, 15(04), 379-413. 
[20] Littunen, H.(2000). Entrepreneurship and the characteristics of the entrepreneurial personality. International Journal of Entrepreneurial Behavior \& Research, Volume 6, Issue 6, p. 295-310.

[21] McClelland, D. C. (1967). Achieving society (Vol. 92051). Simon and Schuster.

[22] McNeil, et al., 1991. Entrepreneurship Success or Failure: Can We Identify the Causes? Journal of Business and Entrepreneurship, Volume 3, Number 1, BI/INFORM, p.35-46.

[23] Moore, R., Lopes, J., 1999. Paper templates. In TEMPLATE’06, 1st International Conference on Template Production. SCITEPRESS. of Entrepreneurship \& Innovation, Vol. 10, No. 2, pp.87-99.

[24] Piperopoulos, P. G. (2016). Entrepreneurship, innovation and business clusters. Routledge.

[25] Ramadani, V., Dana, L. P., Gërguri-Rashiti, S., \& Ratten, V. (Eds.). (2017). Entrepreneurship and Management in an Islamic Context. Springer International Publishing.

[26] Ramadani, V., Gërguri, S., Rexhepi, G. and Abduli, S. (2013) 'Innovation and economic development - the case of FYR of Macedonia', Journal of Balkan and Near Eastern Studies, June, Vol. 15, No. 3, pp.325-346, ISBN 1944-8953.

[27] Ramadani, V., Gërguri, S., Rexhepi, G., \& Abduli, S. (2013). Innovation and economic development: The case of FYR of Macedonia. Journal of Balkan and Near Eastern Studies, 15(3), 324-345.

[28] Ratten, S. G. V. (2015) Entrepreneurship and Management in an Islamic Context. Research), vol. 2, no. 19, pp. 110-116. research', Int. J. Entrepreneurship and Small Business, Vol. 2, No. 1, pp.79-88.

[29] S. A. Hamid and C. Z. Sa"ari. (2011) "Reconstructing entrepreneur"s development based on al-Qur"an and al-Hadith," International Journal of Business and Social Science (The Special Issue on Social Science

[30] Scarborough, N. M., Zimmerer, T. W., \& Naumes, W. (1996). Effective small business management (Vol. 2). Upper Saddle River, NJ: Prentice Hall.

[31] Siswanto, Agus.(2016).The Power of Islamic Entrepreneurship.Jakarta:Amzah Smith, J., 1998. The book, The publishing company. London, $2^{\text {nd }}$ edition.

[32] Talatapeh, M. B. B., \& Nikzad, H. (2016). The Relationship between Islamic Management and Social Entrepreneurship with the Role of Islamic Work Ethic Mediation. Research Journal of Management Reviews. Vol, 2(6), 313-317.

[33] Talatappeh, M. B. B., \& Tavalaee, M. R. (2016). The Components of Islamic Entrepreneurship Pattern Based on Religious Teachings. Modern Applied Science, 10(6), 37. 
[34] Thomas, Z. W., \& Scarborough, N. M. (1996). Entrepreneurship and The New Venture Formation. Upper Saddle River (NJ): Prentice-Hall, 680, 53-56.

[35] Timmons, J. A. (1982). New venture creation: models and methodologies. KENT, C.; SEXTON, D. y VERPER, K.: Encyclopedy of Entrepreneurship. Prentice-Hall. New Jersey.

[36] Zhang, D. and Bruning, E. (2011). Personal characteristics and strategic orientation: entrepreneurs in Canadian manufacturing companies. International Journal of Entrepreneurial Behavior \& Research, Volume 17, Issue 1, p. 82-103

\section{Internet sources}

[37] http://www.gbgindonesia.com/en/manufacturing/article/2016/indonesia _aiming_to_be_the_islamic_fashion_capital_by_2020_11646.php

[38] http://haqislam.org/taqwa/

\section{Appendix}

\section{Appendix. Glossary of Islamic/Arabic Terms}

Allah: The greatest and most inclusive of the names of God. It is an Arabic word of rich and varied meanings, denoting the One True God, the only God who is adored in worship,who creates all that exists and who has priority over all creation.

Falah: Success. Realfalah in this worldly life is a precondition for the falah in the hereafter, which is achieved through "enjoining what is right and forbidding what is evil."

Hadith: Reports on what the Prophet Muhammad (PBUH) said, did and approved of.

Khalifa: successor,regent',viceroy

Qur'an: The Islam's Holy Book, believed by Muslims to be the direct word of The Almighty Allah, revealed to the Prophet Muhammad (PBUH).

Shari'ah: The Islamic law, based on the teachings of the Holy Qur'an; thehadith; and the Noble Sunnah of the Prophet Muhammad (PBUH).

Fathonah: Capable/clever-smart

Amanah: An additional dimension ofamanarelates to the concept of man's role of trustee on earth. As such, he must bear responsibility for his actions. The wealth and other resources that man has access to are not his, but have been loaned to him by God 
as tools to fulfill the responsibilities of the trusteeship. Like any other person, a CEO is accountable for his/her actions, and must devolve the responsibilities associated with his/her position toward other stakeholders (Beekun and Badawi, 2005)

Shiddiq: correct words and deeds.

Tabligh: delivered or treatise devine revelation of Allah to others.

Sunnah: The reported sayings and deeds that proved beyond any doubt to be that of the Prophet (PBUH) or what he witnessed and approved. This is the second source of Islamic law, next to the Holy Qur'an.

Taqwa: the all-encompassing, inner consciousness of one's duty toward Him and the awareness of one's accountability toward Him (Beekun and Badawi, 1999) 